\title{
ANALISIS KEMAMPUAN MULTIREPRESENTASI VERBAL DAN GAMBAR PADA MAHASISWA PENDIDIKAN FISIKA DALAM MEMAHAMI KONSEP REAKSI INTI MATAHARI
}

\author{
Okta Nur Aisyah ${ }^{1}$, Sudarti $^{2}$ \\ oktanuraisyah350@gmail.com \\ ${ }^{1,2}$ Program Studi Pendidikan Fisika FKIP Universitas Jember, Jawa Timur, Indonesia
}

Received: 5 Maret 2021

Revised: 15 Mei 2021

Accepted: 7 Juni 2021

\begin{abstract}
The purpose of this study was to analyze students' ability to analyze a problem using a verbal approach to understanding this material. This study uses a quantitative descriptive method. This research focuses on students' understanding of the theory of the Solar Core Reaction. Sampling was carried out on 3rd semester Physics students in November 2020 using a purposive sampling technique. This study involved 43 respondents from the 3rd semester students of Physics Education at the University of Jember. In this study using an instrument in the form of a questionnaire to collect data. The questionnaire uses the Google Forms application using a verbal and image multi-representation approach. Multi-representation ability is usually used by an educator to be able to more easily deliver the material given to students so that it can be understood by students. Verbal Multirepresentation Ability is a person's ability to understand a theory by using verbal sentences as instruments. Meanwhile, the ability of multi-image representation is a person's ability to understand a theory by using image media. Physics students learn the concept of the Sun's Core Reaction. From the two approaches between the verbal approach and the image approach from the results of this study, students tend to understand more verbal questions with sentences that they are familiar with during their education or with words that are familiar among physics students compared to pictures that they are not sure whether they are This is because some books do not show illustrations or other supporting images to complete the explanation of a theory.
\end{abstract}

Keywords: Picture, Multirepresentation, Vaerbal

\begin{abstract}
Abstrak : Tujuan dari penelitian ini adalah untuk menganalisis kemampuan mahasiswa dalam menganalisis sebuah permasalahan dengan menggunakan pendekatan verbal pada pemahaman materi ini. Penelitian ini menggunakan metode deskriptif kuantitatif. Penelitian ini fokus pada pemahaman mahasiswa mengenai teori tentang Reaksi Inti Matahari. Pengambilan sampel dilakukan pada Mahasiswa semester 3 Fisika pada bulan November 2020 dengan menggunakan teknik purposive sampling. Penelitian ini melibatkan 43 responden dari Mahasiswa semester 3 Pendidikan Fisika Universitas Jember. Pada penelitian ini menggunakan instrumen berupa kuisioner untuk mengumpulkan data. Kuisioner menggunakan aplikasi google Formulir dengan menggunakan pendekatan multirepresentasi verbal dan gambar. Kemampuan Multi representasi biasa digunakan seorang tenaga pendidik untuk dapat lebih mudah dalam penyampaian materi yang diberikan kepada peserta didik agar lebih dapat dipahami oleh peserta didik. Kemampuan Multirepresentasi Verbal adalah kemampuan seseorang untuk memahami sebuah teori dengan menggunakan instrumen kalimat kalimat verbal. Sedangkan Kemampuan multi representasi Gambar adalah kemampuan seseorang untuk memahami sebuah teori dengan menggunakan media gambar. Mahasiswa fisika mempelajari konsep tentang Reaksi Inti Matahari. Dari kedua pendekan antara pendekatan verbal maupun pendekatan gambar dari hasil penilitian ini mahasiswa cenderung lebih memahami pertanyaan pertanyaan verbal dengan kalimat-kalimat yang ia kenal selama menempuh pendidikan atau dengan kata kata yang familiar di kalangan mahasiswa fisika dibandingkan dengan gambar yang ia tidak yakin apakah itu yang dimaksudkan karena dalam beberapa buku tidak memperlihatkan gambar ilustrasi maupun gambar pendukung lainnya untuk melengkapi penjelasan sebuah teori.
\end{abstract}

Kata Kunci : Gambar, Multirepresentasi, Verbal

Puplished at https://ojs.stkippgri-lubuklinggau.ac.id/index.php/SJPIF 


\section{PENDAHULUAN}

Fisika merupakan satu diantara mata pelajaran yang konsepnya dapat direpresentasikan ke dalam berbagai bentuk, yaitu verbal, fisis, gambar dan matematis. Eksperimen dalam pengetahuan sains dan pendidikan fisika menyatakan bahwa ilmuwan sering menerapkan representasi kualitatif seperti gambar dan diagram untuk membantu mereka memahami masalah sebelum menggunakan rumus untuk memecahkan masalah bersifat kuantitatif (Heuvalen dan Xueli, 2001). Fisika Lingkungan adalah salah satu mata kuliah yag ditempuh oleh mahasiswa semester lima pendidika fisika. Salah satu pembahasan pada mata kuliah ini adalah teori reaksi inti matahari dimana mahasiswa pendidikan fisika diharapkan paham reaksi-reaksi saja apa yang terjadi pada matahari. Selain itu sebagai calon pendidik diharapkan mahasiswa dapat memberikan metode pembelajaran yang semenarik mungkin memudahkan siswanya menerima materi yang diberikan. Dalam sebuah proses pendidikan diperlukan sebuah kreasi serta inovasi baru bagi seorang tenaga pendidik untuk menjadikan sebuah pembelajaran menjadi lebih bermakna juga lebih menyenangkan. Fisika selalu menjadi mata pelajaran yang menakutkan bagi kebanyakan peserta didik. Ini adalah salah satu tantangan bagi tenaga pendidik bidang fisika untuk dapat merubah paradigma atau pikiran seperti itu melalui materi ajar fisika menjadi lebih menyenangkan sehingga peserta didik termotivasi untuk mempelajari fisika (Hartini, T. I., \& Martin, M, 2020).

Konsep reaksi inti adalah satu diantara materi fisika yang membutuhkan multirepresentasi untuk pemecahan masalahnya. Materi reaksi inti memerlukan kemampuan pemecahan masalah yang kompleks, artinya mahasiswa tidak hanya menghapalkan rumus, namun siswa harus mengembangkan kemampuan multirepresentasinya secara gambar, diagram dan matematis. Akan menjadi kesulitan mahasiswa untuk menyelesaikan soal-soal fisika pada materi reaksi inti ini jika mereka tidak kuat dalam merepresentasikan konsepkonsepnya menjadi berbagai bentuk (Rizky, G., Tomo, D., \& Haratua, T. M. S, 2014).

Multirepresentasi melibatkan penerjemahan secara berurutan dari masalah fisika yang diberikan dari satu simbol bahasa ke lainnya, dimulai dengan menulis deskripsi masalah secara verbal, kemudian dipindahkan ke bentuk gambar yang disesuaikan dan representasi diagram, dan diakhiri (biasanya) dengan rumus matematis yang dapat digunakan untuk menentukan jawaban menggunakan angka (Leigh, G, 2004). Representasi verbal mewakili suatu konsep atau proses fisika ke dalam bentuk kata-kata atau susunan kalimat. Representasi verbal dapat memberikan pengertian ataupun definisi pada suatu konsep fisika. Representasi gambar adalah representasi yang menyajikan suatu konsep atau proses fisika ke dalam bentuk 
gambar sesungguhnya yang mirip dengan aslinya. Gambar dapat memvisualisasikan konsep yang masih abstrak, sehingga dapat dengan mudah dipahami untuk menuju proses selanjutnya. Representasi fisis adalah penyajian suatu konsep atau proses fisika melalui bentuk fisis seperti diagram benda bebas dan diagram gerak benda (secara kinematis). Representasi matematis mewakili suatu konsep atau proses fisika disajikan ke dalam persamaan matematis. Representasi matematis biasanya diletakkan di akhir, karena fungsinya dapat menentukan hasil akhir suatu proses fisika (Rizky, G., Tomo, D., \& Haratua, T. M. S, 2014).

Seperti penelitian yang dilakukan oleh Fitria (2013) menjelaskan bahwa dengan menggunakan pendekatan multirepresentatif pada suatu pembelajaran dapat memberikan peserta didik sebuah kesempatan untuk lebih memahami konsep fisika melalui berbagai representasi yang berbeda. Dalam mempelajari fisika dibutuhkan kemampuan verbal dan kemampuan gambar untuk memahami suatu teori fisika. Kemampuan verbal merupakan sebuah kemampuan yang dapat menjelaskan suatu pemikiran atau kemampuan mengaitkan beberapa informasi sehingga dapat dihasilakannya sebuah hipotesis.

Pendekatan multirepresentasi juga dapat di gunakan sebagai pendekatan yang ada dalam pembelajaran fisika. Terdapat beberapa representasi untuk pemahaman salah satu konsep fisika yang diperkirakan dapat membantu pemahaman konsep yang telah dipelajari oleh peserta didik. Ini juga terkait dengan kemampuan sfesifik setiap peserta didik yang lebih terlihat daripada kemampuan peserta didik dalam hal lainnya. Ada pula peseta didik yang lebih terlihat kemampuan verbalnya dibandingkan kemampuan lainnya. Kompetensi peserta didik dapat dibentuk ketika siswa tersebut terlibat langsung aktif dalam suatu aktivitas baik mental, fisik, dan sosialnya. Pada SKL mata pelajaran fisika mengisyaratkan pembelajran harus bersifat student centered berbasis kegiatan ilmiah. Siswa perlu dengan pemahaman dari sikap, pengetahuan, serta keterampilan yang didapatnya dari pembelajaran lalu menyesuaikan pengalaman yang meraka milika melalui multi representasi. Peserta didik juga akan belajar lebih efektif dan efisien ketika mereka aktif untuk mengolah informasi dengan multi representasi (David et al, 2013).

Selain tentang ketertarikan peserta didik kepada media yang digunaknnya, dalam pemilihan media juga harus mempertimbangkan mengenai ketersampaian pesan kepada peserta didik oleh guru. Terdapat tiga(3) fungsi yang dapat digunakna untuk mengajar oleh seorang tenaga pendidik. Pertama yaitu media sebagai fungsi stimulasi dimana media dapat menumbuhkan ketertarikan peserta didik untuk mempelajari serta mengetahui lebih lengkap mengenai suatu meteri dalam sebuah media. Selanjutnya adalah fungsi mediasi dimana media Puplished at https://ojs.stkippgri-lubuklinggau.ac.id/index.php/SJPIF 
digunakan untuk perantara peserta didik dan guru dalam berkomunikasi atau menjelaskan suatu materi. Oleh karena itu, media dapat menjadi sebuah jembatan untuk berkomunikasi antara guru dan peserta didik. Dan yang terakhir media fungsi informasi dimana media juga dapat digunakna untuk menjelaskan dengan cara menampilkan apa yang akan disampaikan guru kepada siswa baik berupa pretest atau posttest ataupun berupa kesimpulan. Dengan adanya media, peserta didik dapat menerima penjelasa atau materi yang dibutuhkan peserta didik dengan harapan materi yang diasampaikan guru dapat lebih dipahami (Mahnun, 2012).

Kemampuan Multirepresentasi Verbal adalah kemampuan seseorang untuk memahami sebuah teori dengan menggunakan instrumen kalimat kalimat verbal. Dimana mahasiswa dapat memahami teori hanya memalui kalimat kalimat yang menjelaskan tenteng teoritersebut dan mahasiswa dapat membayangkan teori tersebut. Sedangkan Kemampuan multirepresentasi Gambar adalah kemampuan seseorang untuk memahami sebuah teori dengan menggunakan media gambar. Dalam hal ini mahasiswa dibantu oleh media berupa gambar untuk memahami sebuah reori untuk dapat dibayangan bagaimana terjadianya teori tersebut. Teori Reaksi Inti Matahari adalah salah taori yang tidak dapat kita lihat langsung dalam kehidupan kita tetapi kita dapat merasakan manfaatnya. Kita akan kesusahan jika harus membayangkan bagaimana terjadinya teorireaksi inti matahari. Media adalah salah satu hal paling tepat untuk membantu memahami tentang teori reaksi inti matahari. Terdapat banyak media yang ada saat ini, salah satunya adalah dengan menggunakan gambar sehingga dapat dijadikan sebagai pendukug dari kalimat kalimat verbalnya. Dari permasalahan diatas dijadikan alas an utama peneliti melakukan penelitian yang bertujuan untuk menganalisis kemampuan mahasiswa dalam menganalisis sebuah permasalahan dengan menggunakan pendekatan verbal pada pemahaman materi ini. Penelitian ini menggunakan metode deskriptif kuantitatif. Penelitian ini fokus pada pemahaman mahasiswa mengenai teori tentang Reaksi Inti Matahari.

\section{LANDASAN TEORI}

1. Pendekatan Multirepresentasi

Pendekatan representasi dapat dijadikan sebagai pendekatan dalam pembelajaran fisika. Dari berbagai representasi untuk menanamkan suatu konsep dianggap akan lebih membantu peserta didik untuk memahami konsep yang dipelajari. Hal ini dikarenakan setiap peserta didik memiliki kemampuan khusus yang lebih menonjol dari kemampuan lainnya. Seperti ada peserta didik yang menonjol pada kemampuan verbalnya dibanding dengan kemampuan 
lainnya seperti spasial dan kuantitatifnya, tetapi ada juga yang sebaliknya. Pada penelitian yang dilakukan oleh Van Heuvelen (2001) tentang efek penggunaan multirepresentasi dalam pembelajaran materi usaha-energi terhadap kinerja mahasiswa dalam menyelesaikan persoalan usaha-energi. Peneliti mendapatkan bahwa pendekatan multirepresentasi dapat meningkatkan kinerja mahasiswa dalam menyelesaikan persoalan usaha-energi. Kemampuan analisis mahasiswa terhadap persoalan usaha energi menjadi meningkat(Suhandi et al. 2012 :

2. Pendekatan multirepresentasi

Pendekatan multirepresentasi adalah suatu cara untuk menyatukan suatu konsep dengan berbagai bentuk seperti verbal, grafik, dan matematik(Waldrip et al., 2006 : 87). Maka dengan hal ini multi representasi dapat diartikan suatu cara yang mewakili, melambangkan atau menyatakan suatu konsep dengan memadukan representasi verbal, matematis, gambar, dan grafik(Maharani et al. 2015 : 237).

3. Representasi Verbal

Representasi dalam ilmu psikologi umum menurut Hwang dkk (2007) pada (Putri et al. 2020 : 14 - 41) yang artinya pemodelan hal-hal konkret dalam dunia nyata dalam konsep abstrak atau simbol, sedangkan dalam psikologi matematika representasi diartikan sebagai deskripsi hubungan antara obyek dan simbol. Representasi verbal atau yang biasa disebut dengan bahasa merupakan sebuah kemampuan untuk menerjemahkan sifat dan hubungan yang diamati dalam sebuah masalah matematika kedalam bahasa lisan.

Menurut Gagne dalam (Winkel. 1996 : 323) menyatakan bahwa untuk menemukan kondisi peserta didik yang belajar mengenai infomasi verbal, peserta didik harus memiliki motivasi yangan sangat besar, serta mampu untuk menggunakan bentuk organisasi yang baik sehingga dapat menguasai teknik-teknik yang sesuai, sehingga memiliki ketajaman berpikir dalam menemukan konsep yang tepat, selain itu juga memiliki kemampuan untuk membahasakan makna yang ada di dalam konsep agar dapat tersimpan dalam ingatan dalam bentuk hal yang bermakna.

\section{Representasi Gambar}

Kemampuan representasi gambar atau grafis menurut Hwang dkk (2007) dalam (Putri et al. 2020 : 14 - 41) merupakan sebuah kemampuan yang menerjemahkan masalah matematika dalam bentuk gambar atau grafik. Begitu pula serupa dengan pendapat Cai, dkk. Menyatakan bahwa representasi yang paling sering digunakan dalam komunikasi matematika berupa sajian visual misalnya tabel, gambar, dan grafik, selain itu juga dapat menggunakna pernyataan matematika atau notasi matematika. Representasi gambar informational menyediakan informasi bersifat penting untuk menyelesaikan masalah atau permasalahan Puplished at https://ojs.stkippgri-lubuklinggau.ac.id/index.php/SJPIF 
tersebut didasarkan pada sebuah gambar. Berbeda dengan gambar dekoratif, gambar dekoratif tidak menyediakan informasi penting untuk menyelesaikan masalah, namun gambar hanya digunakan untuk penunjang atau tidak ada hubungan langsung dengan konteks masalah.

Sesuai dengan penelitian yang dilakukan oleh Sujarwanto et al (2014) menyatakan bahwa hasil dari pengamatan dari peneliti selama pemecahan masalah dalam pembelajaran serta hasil analisis paket kuit yang menunjukkan pembuatan representasi tergolong menyulitkan bagi siswa dan hasilnya masih belum sempurna. Representasi masalah yang melalui gambar kurang adanya perubahan yang berarti sampai akhir perlakuan dikarenakan siswa kesulitan untuk membuat diagram benda bebas atau sketsa.

\section{METODE PENELITIAN}

Metode penilitian yang digunakan pada penelitian ini adalah metode deskriptif kuantitatif. Penelitian ini fokus pada pemahaman mahasiswa mengenai teori tentang Reaksi Inti Matahari. Pengambilan sampel dilakukan pada Mahasiswa semester 3 Fisika pada bulan November 2020 dengan menggunakan teknik purposive sampling dimana pengambilan sampelnya peneliti mengandalkan penilaiannya sendiri ketika memilih populasi untuk berpartisipasi dalam penelitian. Penelitian ini melibatkan 43 responden dari Mahasiswa semester 3 Pendidikan Fisika Universitas Jember.

Pada penelitian ini menggunakan instrumen berupa kuisioner untuk mengumpulkan data. Kuisioner menggunakan aplikasi google Formulir dengan menggunakan pendekatan multirepresentasi verbal dan gambar. Soal soal pada kuisioner tersebut meliputi 4 soal verbal salah satunya diwali dengan pengertian dari reaksi inti matahari dimana jika seseorang belum mengetahui apa itu reaksi inti matahari maka kemungkinan kecil mahasiswa tersebut menjawab soal soalberikutnya dengan benar dan 4 soal gambar. Tipe soal yang digunakan adalah Multiple choice sehingga responden hanya memilih jawaban yang tepat saja tanpa harus memberikan alasan kenapa memilih jawaban tersebut.

\section{HASIL DAN PEMBAHASAN}

Penelitian ini digunakan untuk menganalisis kemampuan mahasiswa dalam memahami suatu konsep atau teori dengan menggunakan pendekatan verbal yang berupa kalimat kalimat verbal dan gambar sebagai penjelasan dari kalimat kalimat verbal. Kemampuan mahasiswa dalam menganalisis sebuah permasalahan dengan menggunakan pendekatan verbal pada pemahaman materi ini. Penelitian ini juga dilakukan untuk mencoba penggunaan pendekatan 
multirepresentasi dalam suatu pembelajaran fisika yang khususnya pada teori reaksi inti matahari dalam pembelajaran di tingkat mahasiswa untuk dapat melihat efektivitasnya dalam penanaman konseptual di kalangan mahasiswa. Pendekatan multirepresentasi memiliki keunggulan dalam memfasilitasi mahasiswa yang memiliki kemampuan sangat beragam.

Tabel 1. Hasil presentase dari kuisioner analisis pemahaman mahasiswa fisika pada materi reaksi inti matahari

\begin{tabular}{ccc}
\hline $\begin{array}{c}\text { Jenis } \\
\text { Pertanyaan }\end{array}$ & $\begin{array}{c}\text { Nomor } \\
\text { Pertanyaan }\end{array}$ & Presentase \\
\hline \multirow{3}{*}{ Verbal } & 1 & $69,8 \%$ \\
& 2 & $41,9 \%$ \\
& 3 & $23,3 \%$ \\
Gambar & 4 & $60,5 \%$ \\
& 5 & $9,3 \%$ \\
& 6 & $46,5 \%$ \\
& 8 & $23,3 \%$ \\
\hline
\end{tabular}

Hasil kuisioner yang telah dibagikan kepada mahasiswa fisika semester 3 terdapat 80,9 $\%$ dari responden memahami tentang yang dimaksud dari reaksi inti matahari namum belum sepenuhnya memahami mengenai reaksi fisi dan reaksi fusi sehingga masih banyak mahasiswa tang terbalik antara rekasi fisi dan reaksi fusi. Begitu pula pada pertanyaan yang menggunakan gambar, mahasiswa cenderung tidak teliti dengan gambar yang diberikan sehingga mahasiswa masih terdapat kesalahan dalam menjawab pertanyaan berupa gambar.

Pada pertanyaan verbal presentase pemahaman mahasiswa lebih besar daripada menggunakan gambar. Pertanyaan pertama terdapat 30 responden menjawab benar dari total 43 responden yang mengetahui apa yang dimaksud dengan reaksi inti matahari. Pada soal kedua mengenai hukum apa yang berlaku pada reaksi inti matahari terdapat 18 masiswa yang menjawab benar, sehingga untuk soal selanjutnya yang membahasa mengenai hukum yang berlaku pada reaksi inti kurang dari 50\% responden yang menjawab benar seperti pada halnya pertanyaan nomor 3 tentang persamaan yang tejadi ketika pelepasan energi pada reaksi eksoterm terdapat 10 responden yang menjawab benar dari total responden. Namun pada pertanyaan verbal yang ke empat terdapat 26 responden yang menjawab benar mengenai jumlah proton dan neutron pada reaksi yang diberikan.

Kemampuan responden dalam menjawab pertanyaan verbal tergolong lebih baik karena masih terdapat beberapa pertanyaan yang lebih banyak menjawab benar. Pada pertanyaan menggunakan ilustrasi gambar tentang reaksi deret yang ada pada reaksi fisi hasilnya terdapat 4 responden saja yang menjawab benar. Sedangkan pada pertanyaan tentang menunjukkan komponen dasar dari reaktor terdapat 20 responden menjawab benar sehingga dianggap 
responden tersebut mengetahui mengenai komponen komponen dari reaktor. Sedangkan pada pertanyaan ke tujuh mengenai mengenai jumlah reaksi yang dihasilkan oleh atom Helium terdapat 10 orang yang menjawab benar. Begitu pula pada pertanyaan terakhir mengenai suhu dari salah satu lapisan matahari terdapat 22 responden yang menjawab benar.

Pendekatan antara pendekatan verbal maupun pendekatan gambar dari hasil penilitian ini mahasiswa cenderung lebih memahami pertanyaan pertanyaan verbal dengan kalimat kalimat yang ia kenal selama menempuh pendidikan atau dengan kata kata yang familiar bagi mahasiswa fisika dibandingkan dengan gambar yang ia tidak yakin apakah itu yang dimaksudkan karena dalam kebanyakan buku tidak memperlihatkan gambar ilustrasi maupun pendukung lainnya untuk melengkapi penjelasan sebuah teori. Selain itu mahasiswa juga masih menganggap materi mengenai inti matahari adalah salah satu materi yang abstrak dimana materi tersebut sulit untuk dibayangakn kejadian atau peristiwanya.

\section{SIMPULAN DAN SARAN}

Kemampuan Multirepresentasi Verbal adalah kemampuan seseorang untuk memahami sebuah teori dengan menggunakan instrumen kalimat kalimat verbal. Kemampuan representasi Gambar adalah kemampuan seseorang untuk memahami sebuah teori dengan menggunakan media gambar. Terdapat perbedaan presentase antara jumlah responden yang soal verbal dengan benar lebih banyak daripada jumlah responden yang menjawab benar soal representasi gambar. Menurut Sujarwanto et al (2014) menyatakan bahwa siswa merasa kesulitan dalam pembuatan representasi (grafik, diagram) saat pembelajaran maupun saat pemecahan masalah (tes/kuis).

Dari hasil kuisioner tersebut dapat ditarik kesimpulkan bahwa mahasiswa cenderung lebih memahami dengan menggunakan pendekatan verbal dibandingkan dengan pendekatan gambar karena mahasiswa kebanyakan belum memahami proses reaksi inti matahari sehingga ketika dimunculkan berpa gambar mahasiswa masih membayangkan prosesnya sehingga kebanyakan mahasiswa menjawab kurang tepat.

Diharapkan untuk pembaca agar lebih memahami atau memiliki sumber referensi lain mengenai pendekatan verbal, pendekatan gambar serta teori reaksi inti matahari agar tidak salah faham ketika membaca dapat memahami materi yang dibahas. 


\section{DAFTAR PUSTAKA}

David, M.J. Cristophe, D.J. Norma, A.J. 2013. The Effect Of Representations On Difficulty Perception And Learning Of The Physical Concept Of Pressure. Thems In Science And Technology Education, Vol 6(2) : 91-108.

Fitria, I. (2013). Pengunaan Model Problem Based Learning dengan Multirepresentasi pada Materi Usaha dan Energi di SMA. Journal Fisika.

Hartini, T. I., \& Martin, M. (2020). Pengaruh Penggunaan Model Pembelajaran Problem Solving Sistematis terhadap Hasil Belajar Fisika Dasar 2 Materi Listrik Arus Searah pada Mahasiswa Pendidikan Fisika. SILAMPARI JURNAL PENDIDIKAN ILMU FISIKA, 2(2), 163-174.

Irawan . A., Gita K. 2016. Peranan Kemampuan Vebal dan Kemampuan Nomerik terhadap kemampuan Berpikir Kritis Matematika. Jurnal Pendidikan Matematika. Vol 5(2) : 110.

Kartini. 2009. Peranan Representasi dalam Pembelajaran Matematika. Prosiding dalam Pembelajaran Matematika. Prosiding dalam Seminar Nasional Matematika dan Pendidikan Matematika, 361-372.

Kumara, Amitya. 2001. Dampak Kemampuan Verbal Terhadap Ekspresi Tulis. Jurnal Psikologi. Vol1(1) : 35-40.

Leigh, G. (2004). Developing multi-representational problem solving skills in large, mixedability physics classes (Master's thesis, University of Cape Town).

Maharani. D., T. Prihandono, A. D. Lesmono. 2015. Pengembangan LKS Multirepresentasi Berbasis Pemecahan Masalah pada Pembelajaran Fisika di SMA. Jurnal Pembelajaran Fisika. Vol. 4(3) : 237.

Mahnun. Nunu. 2012. Media Pembelajaran (Kajian terhadap Langkah-langkah Pemilihan Media dan Implementasinya dalam Pembelajaran). Jurnal Pemikiran Islam. Vol. $37(1): 27-29$.

Prahani, B.K., Soegimin, W.W, Leny, Y. 2015. Pengembangan Perangkat Pembelajaran Fisika Model Inkuiri Terbimbing Untuk Melatihkan Kemampuan Multi Representasi Siswa SMA. Pendidikan Sains Pascasarjana Universitas Negeri Surabaya Vol. 4(2).

Putri. H. E., I. Muqodas, M. A. Wahyudy, A. Abdulloh, A. S. Sasqia, L. A. N. Afita. 2020. Kemampuan-Kemampuan Matematis dan Pengembangan Instrumennya. Jawa Barat : UPI Sumedang Press.

Rizky, G., Tomo, D., \& Haratua, T. M. S. (2014). Kemampuan multirepresentasi siswa SMA dalam menyelesaikan soal-soal hukum Newton. Jurnal Pendidikan dan Pembelajaran Khatulistiwa, 3(8).

Suhandi. A., Wibowo. F.C. 2012. Pendekatan Multirepresentasi dalam Pembelajaran UsahaEnergi dan Dampak Terhadap Pemahaman Konsep Mahasiswa. Jurnal Pendidikan Fisika Indonesia. $8: 1-7$. 
Sugiyono. 2008. Metode Penelitian Pendidikan. Bandung : Alfabeta.

Sujarwanto. E., A. Hidayat, Wartono. 2014. Kemampuan Pemecahan Amsalah Fisika pada Modeling Instruction Pada Siswa SMA Kelas XI. Jurnal Pendidikan IPA Indonesia. Vol 3(1) : 73 .

Van Heuvelen, A., \& Zou, X. (2001). Multiple representations of work-energy processes. American Journal of Physics, 69(2), 184-194.

Waldrip, B., Prain, V., dan Carolan, J. 2006. Learning Junior Secondary Science through Multi-Modal Representations. Electronic Journal of Science Education. Vol. 11 (1) : $87-107$.

Widianingtyas. L., Siswoyo, Fauzi. B., 2015. Pengaruh Pendekatan Multi Representasi dalam Pembelajaran Fisika Terhadap Kemampuan Kognitif Siswa SMA. Jurnal Penelitian \& Pengembangan Pendidikan Fisika. Vol 1(1). 